\title{
Anti-Inflammatory and Anti-Oxidative Synergistic Effect of Vitamin D and Nutritional Complex on Retinal Pigment Epithelial and Endothelial Cell Lines against Age-Related Macular Degeneration
}

\author{
Maria Hernandez ${ }^{1,2,3, *,+}$, Sergio Recalde ${ }^{1,2,3,+} \mathbb{D}$, Jorge González-Zamora ${ }^{1}$, Valentina Bilbao-Malavé ${ }^{1}$, \\ Manuel Sáenz de Viteri 1,2,3,+ $\mathbb{D}$, Jaione Bezunartea ${ }^{1,2}$, Maite Moreno-Orduña 1,2, Idoia Belza ${ }^{1}$, \\ Jesús Barrio-Barrio 1,3 (D), Patricia Fernandez-Robredo 1,2,3,+ and Alfredo García-Layana 1,2,3,+
}

1 Retinal Pathologies and New Therapies Group, Experimental Ophthalmology Laboratory, Department of Ophthalmology, Clinica Universidad de Navarra, 31008 Pamplona, Spain; srecalde@unav.es (S.R.); jgzamora@unav.es (J.G.-Z.); vbilbao@unav.es (V.B.-M.); msaenzdevit@unav.es (M.S.d.V.); jbezunartea@unav.es (J.B.); maimoreno@unav.es (M.M.-O.); idoiabelza@unav.es (I.B.); jbarrio@unav.es (J.B.-B.); pfrobredo@unav.es (P.F.-R.); aglayana@unav.es (A.G.-L.)

2 Navarra Institute for Health Research, IdiSNA, 31008 Pamplona, Spain

check for updates

Citation: Hernandez, M.; Recalde, S. González-Zamora, J.; Bilbao-Malavé, V.; Sáenz de Viteri, M.; Bezunartea, J.; Moreno-Orduña, M.; Belza, I.; Barrio-Barrio, J.; Fernandez-Robredo, P.; et al. Anti-Inflammatory and Anti-Oxidative Synergistic Effect of Vitamin D and Nutritional Complex on Retinal Pigment Epithelial and Endothelial Cell Lines against Age-Related Macular Degeneration. Nutrients 2021, 13, 1423. https:// doi.org/10.3390/nu13051423

Academic Editor: Carsten Carlberg

Received: 18 February 2021

Accepted: 21 April 2021

Published: 23 April 2021

Publisher's Note: MDPI stays neutral with regard to jurisdictional claims in published maps and institutional affiliations.

Copyright: (c) 2021 by the authors. Licensee MDPI, Basel, Switzerland. This article is an open access article distributed under the terms and conditions of the Creative Commons Attribution (CC BY) license (https:/ / creativecommons.org/licenses/by/ $4.0 /)$.
3 Red Temática de Investigación Cooperativa Sanitaria en Enfermedades Oculares (Oftared), 31008 Pamplona, Spain

* Correspondence: mahersan@unav.es

+ These authors contributed equally to this work.

\begin{abstract}
Age-related macular degeneration (AMD) is a multifactorial disease of the retina featured by dysfunction of retinal pigmented epithelial (RPE) and loss of photoreceptor cells under oxidative stress and inflammatory conditions. Vitamin D and antioxidants have beneficial effects against retinal degenerative diseases, such as AMD. We investigated the impact of associating vitamin D (ND) with a nutritional antioxidant complex (Nutrof Total ${ }^{\circledR} ; \mathrm{N}$ ) on oxidative stress and inflammation-like induced conditions by $\mathrm{H}_{2} \mathrm{O}_{2}$ and LPS, respectively, in human retinal epithelial (ARPE-19) and human retinal endothelial (HREC) cells. Application of either $\mathrm{N}$ or ND treatments to $\mathrm{H}_{2} \mathrm{O}_{2}$-induced media in ARPE-19 cells counteracted late apoptosis, attenuated oxidative DNA damage, and increased cell proliferation. Significant reduction in the expression levels of MCP1, IL-8, and IL6 cytokines was observed following application of either $\mathrm{N}$ or ND treatments under LPS-induced conditions in ARPE-19 cells and in MCP-1 and IL12p70 cytokine levels in HREC cells. ND and not N revealed significant downregulation of IFN $\gamma$ in ARPE-19 cells, and of IL-6 and IL-18 in HREC cells. In conclusion, adding vitamin D to Nutrof Total ${ }^{\circledR}$ protects in a synergistic way against oxidative and inflammatory stress-induced conditions in retinal epithelial and endothelial cells.
\end{abstract}

Keywords: vitamin D; nutritional complex; AMD; inflammation; oxidative stress; retina

\section{Introduction}

Age-related macular degeneration (AMD) is a chronic progressive degenerative eye disease that gradually destroys the macula, leading to irreversible blurred vision or vision loss [1-3]. AMD is the primary cause of visual impairment in the elderly, and without an effective treatment, the prevalence of AMD is estimated to increase by $40 \%$ by 2040 [4].

AMD is clinically classified as early-, intermediate-, or late-stage depending on the size of drusen and on pigmentary abnormalities. Late-stage is linked to neovascular or geographic atrophy AMD [3,5]. Neovascularization of the retina is implicated in the development of abnormal blood vessels that penetrate Bruch's membrane from the choroid and lead to progressive damage of the retinal pigmented epithelium (RPE) cell layer and of the photoreceptors in proximity [2]. The pathogenesis of AMD is well described as the 
outcome of complex multifactorial interactions involving genetic, metabolic, functional, and environmental factors [6-13]. These factors result in overproduction of reactive oxygen species, and thus accumulation of oxygen radicals and oxidative stress in RPE $[14,15]$ can lead to dysfunction of RPE, which subsequently affects the nutrition of photoreceptors, resulting in angiogenesis and choroidal neovascularization (CNV) [16,17].

Currently, anti-vascular endothelial factor (VEGF) therapy is administered as an intravitreal injection to regress development to wet AMD [1], while no preventive therapy exists for dry AMD. Treatment with anti-VEGF agents is not always effective, with certain patients experiencing recurrent symptoms of exudation and additional injections leading to patient compliance issues, undesirable side effects, and increased financial burden to the healthcare system or the patient [18].

Therefore, antioxidant formulations (consisting primarily of vitamins $\mathrm{C}$ and $\mathrm{E}$ ) and mineral supplementation (zinc, copper) have been examined in two earlier sequential clinical trial studies (Age-Related Eye Disease Study (AREDS and AREDS2)), sponsored by the National Eye Institute, showing reduced 5-year risk on progressing from intermediate to advanced AMD by about $25 \%$ in participants taking antioxidant formulation along with zinc and copper compared to those originally assigned to placebo $[19,20]$. The nutritional antioxidant complex in this study contains antioxidant vitamins and trace elements, natural components (lutein and zeaxanthin), and resveratrol, and is enriched in fish oil (Table S1).

Previous studies have demonstrated a relationship between deficient levels of vitamin $\mathrm{D}$ and onset or development of AMD [16,21-30], suggesting that vitamin D administration can be protective or preventive from progression to neovascular AMD. Recent studies have reported expression of vitamin D receptors throughout the eye, including the retina [31,32], where they are expressed by human retinal pigment epithelial cells (ARPE-19) [31,33] and retinal endothelial cells [34], suggesting vitamin D's functional significance in the ocular system [35]. Moreover, a recent study has reported expression of vitamin D-synthesizing components in ARPE-19 and HREC cells [36]. The expression of vitamin D receptors in RPE cells has been previously demonstrated by our group, using PCR experiments [36], and by other investigators who demonstrated by immunohistochemical staining presence of vitamin D receptors throughout the RPE [37] as well as by whole-transcriptome expression profiles in the RPE-choroid region collected from human donors [38].

Numerous observational studies have investigated the association between vitamin $\mathrm{D}$ and $\mathrm{AMD}$, with current data remaining inconclusive and controversial. For example, a meta-analysis of 11 observational studies demonstrated an inverse relationship between low levels of plasma vitamin D levels and late AMD [23], while others with early AMD [21,39]. However, a recent review reported no evidence of a relationship between vitamin D levels and risk for AMD [40-43]. Additionally, an inconsistent relationship exists between vitamin $\mathrm{D}$ status and AMD in the epidemiological context to date. For example, in a prospective 18-year follow-up analysis of participants in the Atherosclerosis Risk in Communities Study, a statistically inversed relationship was found to exist between incidence of AMD and low vitamin D concentrations [26]. A protective relationship between early AMD and vitamin D serum levels was observed in a cohort of African Americans and Caucasians [27] and in non-Hispanic white, non-Hispanic black, and Mexican Americans. However, it was only statistically significant among non-Hispanic whites [21]. On the other hand, no overall statistically significant relationship was described in a survey of Korean adults [43] in a retrospective cohort of Medicare beneficiaries [41] and in an elderly cohort of French participants [42] between vitamin D concentrations and early or late AMD.

In this study, we would like to provide additional evidence on the potential impact of vitamin D in AMD. Therefore, vitamin D was added to the nutritional antioxidant complex to investigate both their potential synergistic effect and individual outcome on oxidation and inflammation-induced damage, which play a key role in retinal degenerative diseases including AMD. To this end, we examined the potential protective effect of these treatments on cell integrity, cell proliferation, DNA oxidative damage, apoptosis, and cytokine expression levels in ARPE-19 and human retinal endothelial cells (HREC). 


\section{Materials and Methods}

\subsection{Cell Culture}

The same cell lines and culture system were used as previously described [36]. Briefly, human retinal pigment epithelial cells, ARPE-19 (CRL-2302, ATCC, Manassas, VG, USA; 3 passages) were grown to confluence in a standard incubator in DMEM (D6429, Sigma-Aldrich, St Louis, MO, USA) containing 10\% fetal bovine serum (FBS; 10270106 Gibco $^{\mathrm{TM}}$ ThermoFisher, Paisley, UK), $1 \%$ fungizone $\left(\mathrm{Gibco}^{\mathrm{TM}}\right)$, and penicillin-streptomycin $\left(\mathrm{Gibco}^{\mathrm{TM}}\right)$. Human retinal endothelial cells (HREC; p10880, Innoprot, Vizcaya, Spain) after being seeded in T75 flasks were covered with $1 \mathrm{mg} / \mathrm{mL}$ of fibronectin (Innoprot, p8248) and grown to confluence in a standard incubator in Endothelial Cell Medium (Innoprot) containing 5\% FBS (Innoprot), 1\% Endothelial Cell Grow Supplement (ECGS; Innoprot), and penicillin-streptomycin solution (Innoprot).

\subsection{Stable Cell Line Phenotypic Characterization}

As previously described [36], immunofluorescence with RPE65 (1:100, 78036, Abcam, Cambridge, USA) and caveolin (1:250, 3238S, Cell Signalling, Danvers, MA, USA) was performed for ARPE-19 and HREC cells, respectively. Briefly, 100,000 ARPE-19 and 50,000 HREC cells were seeded on a $10 \mathrm{~mm}$ dish (Menzel-Glaser, Waltham, MA, USA) and following cellular fixation with cold methanol, cells were blocked with $1 \%$ BSA, $0.5 \%$ Triton $\mathrm{X}-100,0.2 \%$ sodium azide, and $1 \% \mathrm{FBS}$ for $1 \mathrm{~h}$ at $4{ }^{\circ} \mathrm{C}$. Cells were then incubated with the primary antibodies at $4{ }^{\circ} \mathrm{C}$ for $24 \mathrm{~h}$ and subsequently incubated for $1 \mathrm{~h}$ at room temperature with the secondary fluorescent antibodies goat anti-mouse 488 (1:250, A11029, Life Technologies, Gaithersburg, MD, USA) for caveolin marker and donkey anti-rabbit 488 (1:250, A21206, Invitrogen, Carlsbad, CA, USA) for RPE65 marker, accordingly. Nuclei were labelled with DAPI (6-diamidino-2-phenylindole; Sigma-Aldrich, St Louis, MO, USA). Fluorescent images were obtained using a confocal microscope (LSM800, Zeiss, Oberkochen, Germany).

\subsection{Experimental Design}

\subsubsection{Oxidative Stress and Inflammatory-Like Conditions}

ARPE-19 and HREC cell lines were incubated for $2 \mathrm{~h}$ with hydrogen peroxide $\left(\mathrm{H}_{2} \mathrm{O}_{2}\right.$; either 600, 1000, or $1600 \mu \mathrm{M}$, according to the experiment; Panreac, Barcelona, Spain) to induce in vitro oxidative stress, and for $24 \mathrm{~h}$ with lipopolysaccharide (LPS; $20 \mu \mathrm{g} / \mathrm{mL}$ for ARPE-19 and $50 \mu \mathrm{g} / \mathrm{mL}$ for HREC cells; Sigma-Aldrich, St. Louis, MO, USA) to induce an inflammatory response, respectively. Saline was used as negative control. Cells were collected at the end of the induction time.

\subsubsection{Treatments with the Nutritional Antioxidant Complex (Nutrof Total ${ }^{\circledR}$ ) and Vitamin D}

During the last hour of the induction time, prior to cell harvesting, cells were treated with either Nutrof Total ${ }^{\circledR}(\mathrm{N} ; 62.34 \mu \mathrm{g} / \mathrm{mL}$, see Table S1 for composition; from Thea Laboratoires, Clermont-Ferrand, France) or Nutrof Total ${ }^{\circledR}$ plus $1 \mathrm{nM}$ vitamin D (ND) at a total equivalent concentration of $62.34 \mu \mathrm{g} / \mathrm{mL}$. This concentration was used for both $\mathrm{N}$ and ND treatments in our experiments in order to have consistency in our comparisons between $\mathrm{N}$ and ND treatments.

\subsection{Cell Viability/Cytotoxicity Assay (MTT), and Proliferation Assay (Bromodeoxyuridine, BrdU)}

Cell viability/cytotoxicity and cell proliferation in ARPE-19 and HREC cell lines was determined by the 3-(4,5-dimethylthiazol-2-yl)-2,5-diphenyltetrazolium bromide (MTT) reduction assay CellTiter 96 Aqueous One Solution Cell Proliferation Assay (Promega, Madison, WI, USA), and by the Calbiochem BrdU Cell Proliferation Assay (Calbiochem, La Jolla, CA, USA), respectively, according to the manufacturer's instructions, as previously described [36].

Cells were exposed to $\mathrm{N}$ and ND treatments for $24 \mathrm{~h}$ to examine their effect on cytotoxicity. Two different concentrations for vitamin $\mathrm{D}(1 \mathrm{nM}$ and $5 \mathrm{nM})$ were selected as 
being safe [36]. Consequently, the equivalent ND concentrations were calculated on the basis of these vitamin D values (ND1: $62.34 \mu \mathrm{g} / \mathrm{mL}$ and ND5: $311.7 \mu \mathrm{g} / \mathrm{mL}$ ). To examine cell proliferation, cell lines were exposed to $1000 \mu \mathrm{M} \mathrm{H}_{2} \mathrm{O}_{2}$ for $2 \mathrm{~h}$ to induce oxidative stress conditions, while $\mathrm{N}$ and ND treatments $(62.34 \mu \mathrm{g} / \mathrm{mL}$ each) were applied individually to $\mathrm{H}_{2} \mathrm{O}_{2}$-induced media during the last hour of the induction time.

\subsection{Zonula Occludens (ZO-1) Immunofluorescence for Cell Structure and Integrity}

Immunofluorescence against zonula occludens-1 (ZO-1) was performed to assess the effect of both $\mathrm{N}$ and ND treatments on intercellular tight junctions. ARPE-19 cells were seeded at a density of 100,000 cells per well on laminin-coated polycarbonate membrane cell culture inserts (Corning Life Science, Tewksbury, MA, USA) and were grown in 1\% serumfree DMEM for 4 weeks. Immunofluorescence was then performed using a ZO-1 anti-rabbit Alexa Fluor 594 antibody (1:100, 339194, Invitrogen- Life Technologies, Carlsbad, CA, USA) diluted in blocking buffer following the same protocol as previously described [36]. DAPI (6-diamidino-2-phenylindole; Sigma-Aldrich) was used to stain cell nuclei. Images were obtained with a laser scanning confocal imaging system (LSM800, Zeiss, Oberkochen, Germany). N and ND treatments $(62.34 \mu \mathrm{g} / \mathrm{mL})$ were added individually to the cell line in order to be compared to the saline group, and were also added with either $\mathrm{H}_{2} \mathrm{O}_{2}$ $(1600 \mu \mathrm{M})$ or LPS (as described in Section 2.3) in order to identify potential recovery effects on cell integrity.

\subsection{Cell Apoptosis Assay}

Apoptosis assay was performed as previously described [36]. Briefly, apoptosis in ARPE-19 cells was detected in cultured plates using in situ cell death detection kit with TMR Red (\#12 156792910, Roche, West Sussex, UK) following the manufacturer's instructions. Nuclei were labelled with DAPI and images were obtained using a confocal microscope (LSM800, Zeiss, Oberkochen, Germany). N and ND treatments $(62.34 \mu \mathrm{g} / \mathrm{mL})$ were added individually to ARPE-19 cells in order to be compared to the saline group, and were also added with either $\mathrm{H}_{2} \mathrm{O}_{2}(600 \mu \mathrm{M})$ or LPS (as described in Section 2.3) in order to identify potential preventive effects on cell apoptosis.

\subsection{Evaluation of Oxidative DNA Damage by 8-Hydroxidioguanosine (8-OHdG)}

Oxidative damage to DNA was measured under oxidative stress conditions in ARPE19 supernatants subjected to $\mathrm{H}_{2} \mathrm{O}_{2}(1000 \mu \mathrm{M})$, as described in Section 2.3. During the last hour of the induction time, cells were exposed to either N or ND treatments $(62.34 \mu \mathrm{g} / \mathrm{mL})$, and supernatants were subsequently collected and measured by an enzyme-linked immunosorbent assay (ELISA) kit \#ab201734 (Abcam, Cambridge, MA, USA).

\subsection{Cytokine Analysis}

As previously described [36], cytokine analysis was performed by the FirePlex Firefly ${ }^{\circledR}$ and Analysis Workbench (Abcam, Cambridge, MA, USA), a software for multiplex protein expression assays, whereby supernatants were measured under LPS-induced inflammatory conditions, as described in Section 2.3, and compared with supernatants after subsequent addition of either $\mathrm{N}$ or ND treatments $(63.34 \mu \mathrm{g} / \mathrm{mL})$ during the last hour of the induction time. The cytokines investigated in both ARPE-19 and HREC cells included interleukin (IL)-1 $\beta$, IL-6, IL -8, IL-10, IL-12p70, IL-18, interferon (IFN)- $\gamma$, monocyte chemoattractant protein (MCP)-1, and tumor necrosis factor (TNF)- $\alpha$. All cytokines are expressed in $\mathrm{pg} / \mathrm{mL}$, except for MCP-1 and IL-8, which were expressed as ng/mL.

\subsection{Statistical Analysis}

To determine whether variables followed a normal distribution, we applied the ShapiroWilk and Levene tests to assess variance homogeneity. All parameters were subjected to analysis of variance (ANOVA) or Kruskal-Wallis test followed by Bonferroni post hoc 
test. A difference of $p<0.05$ was considered statistically significant. GraphPad Prism 6.0 (GraphPad Prism Software Inc., San Diego, CA, USA) was used for statistical analysis.

\section{Results}

The phenotype of both ARPE-19 and HREC cells was stable under immunofluorescence staining with the corresponding RPE65 and caveolin markers (Figure S1), and no cytotoxicity was observed even at five times higher the optimized concentration by MTT assay (Figure S2).

\subsection{Effect of $N$ and $N D$ Treatments on Junctional Integrity}

In order to assess the effect of oxidative stress and inflammation on tight junctions of ARPE-19 cells, we examined ZO-1 by immunofluorescence. There were disruptions and a reduction of immunofluorescence staining in the integrity of the apical areas of epithelial monolayer under oxidative stress induced by $\mathrm{H}_{2} \mathrm{O}_{2}$ (Figure 1D) compared to saline conditions (Figure 1A). Similarly, ZO-1 immunofluorescent staining under LPSinduced inflammation showed a disruption in cell contact (Figure 1G) in comparison to basal conditions (Figure 1A). Application of either N or ND treatments to the cell line showed formation of stable tight junctions (Figure 1B,C) similar to saline conditions (Figure 1A). Interestingly, when $\mathrm{N}$ and $\mathrm{ND}$ treatments were added in $\mathrm{H}_{2} \mathrm{O}_{2}-$ (Figure $1 \mathrm{E}, \mathrm{F}$ ) and LPS-induced media (Figure 1H,I), they recovered the effect of oxidative stress and inflammation (Figure 1D,G) contributing to maintenance of cell polarity, suggesting a protective effect of N and ND on tight junctions and integrity in ARPE-19 cells.

\subsection{Effect of $N$ and $N D$ treatments on Apoptosis and Cell Proliferation}

TDT-mediated dUTP-biotin nick end-labeling (TUNEL) revealed no presence of apoptotic ARPE-19 cells following addition of either $\mathrm{N}$ or ND treatments to the culture media (Figure 2C,D), similar to saline conditions (Figure 2A). Application of $\mathrm{H}_{2} \mathrm{O}_{2}$ to induce oxidative stress showed increased TUNEL-positive immunostaining of ARPE-19 cells (Figure 2B) compared to saline conditions (Figure 2A), which was counteracted by addition of either $\mathrm{N}$ or ND treatments to the oxidative stress-induced media (Figure 2C,D).

Oxidative stress plays a critical role in the development and progression of AMD. Increased reactive oxygen species may cause RPE cell dysfunction leading to AMD. Therefore, cell proliferation assay was performed in order to examine the antioxidant effect of the two formulations in recovering cell viability and to align the outcome with the apoptosis assay (TUNEL staining). In addition, cell proliferation, as assessed by BrdU expression levels, was significantly reduced in ARPE-19 $(p<0.001$; Figure 2G) and HREC $(p<0.05$; Figure $2 \mathrm{H}$ ) cells subjected to $\mathrm{H}_{2} \mathrm{O}_{2}$-induced oxidative stress. After application of either $\mathrm{N}$ or ND treatment to the oxidative stress-induced media, there was significant recovery and increased cell proliferation compared to $\mathrm{H}_{2} \mathrm{O}_{2}$ alone $(p<0.001$ and $p<0.01$ for $\mathrm{N}$ and ND, respectively, Figure 2G) in ARPE-19 cells. In the case of HREC cells, there was a trend towards recovery of cell proliferation and increased BrdU levels, being more potent with addition of ND than N; however, it did not reach statistical significance (Figure 2H).

\subsection{Antioxidant properties of $N$ and $N D$ treatments}

Figure 3 shows that oxidative stress induced by $\mathrm{H}_{2} \mathrm{O}_{2}$ significantly $(p<0.05)$ increased the expression levels of the marker representative for oxidative damage to DNA, 8-OHdG, in supernatants from ARPE-19 cells. Addition of either N or ND to the cells under induced oxidative stress resulted in a tendency to reduce 8-OHdG expression levels ( $p=0.08$ for ND).

\subsection{Regulation of Inflammatory Cytokines by N and ND Treatments}

Figure 4A shows that inflammation induced by LPS significantly $(p<0.05)$ increased the expression levels of IL-8, MCP-1, TNF $\alpha$, IFN $\gamma$, IL-6, and IL-12p70 cytokines in ARPE-19 cells. Under LPS-induced inflammatory-like conditions, application of either N or ND 
treatment to the media significantly $(p<0.05)$ downregulated the expression of IL-8, IL-6, and MCP-1. Significant reduction of IFN $\gamma$ expression levels was observed only upon addition of ND $(p<0.05)$ and not $\mathrm{N}(p=0.068)$. Interestingly, addition of $\mathrm{N}$ showed a strong tendency to reduce TNF $\alpha$ expression levels $(p=0.111)$ when added in inflammatoryinduced ARPE-19 cells.

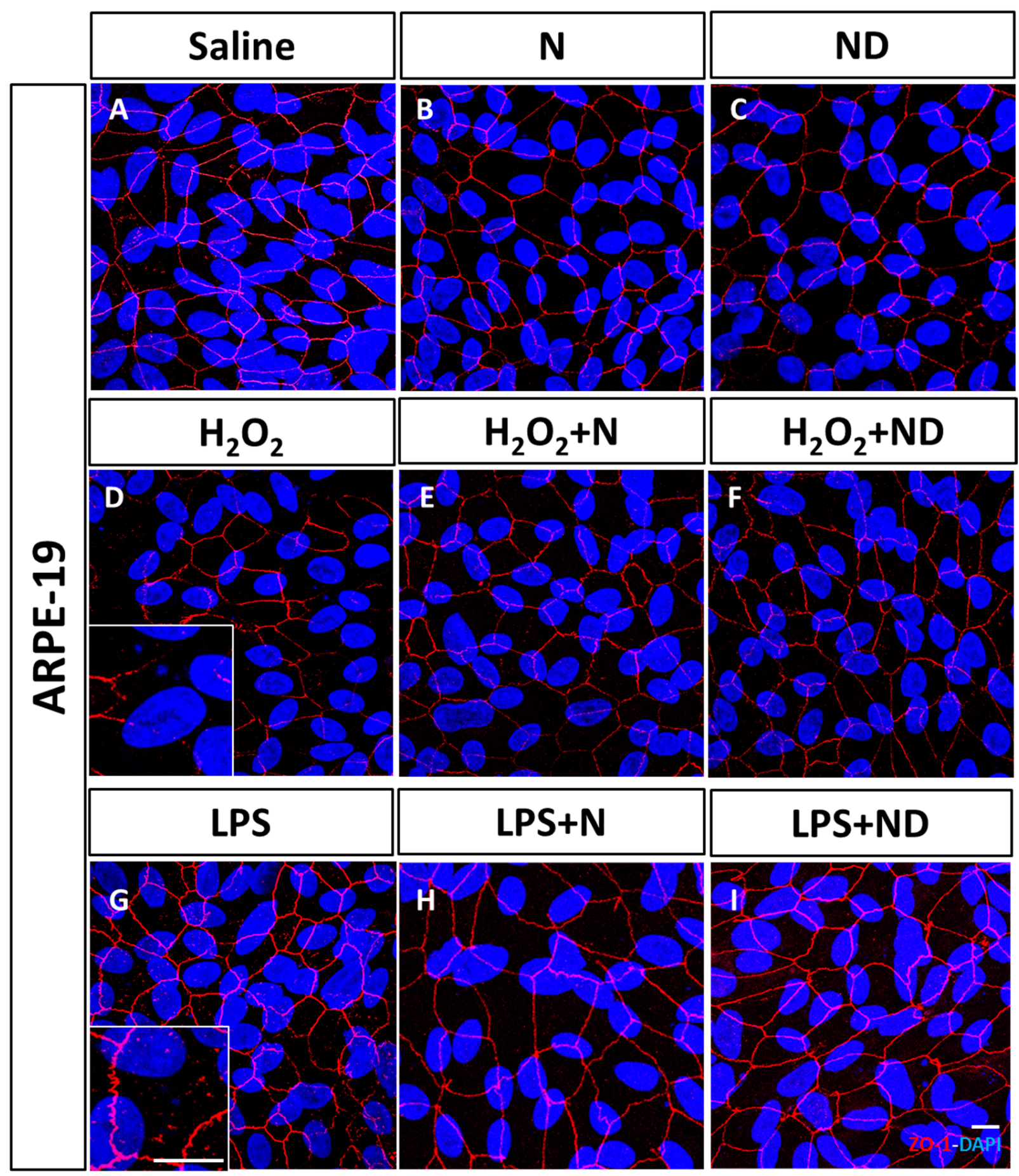

Figure 1. Junctional integrity of ARPE-19 cells evaluated by ZO-1 (red) fluorescence under a confocal imaging system. Application of $\mathrm{N}$ and ND treatments $(62.34 \mu \mathrm{g} / \mathrm{mL}$ each) did not affect tight junctions, cell integrity, and structure (B,C) compared to saline (A). Addition of $\mathrm{H}_{2} \mathrm{O}_{2}(2 \mathrm{~h} ; 1600 \mu \mathrm{M})$ and LPS $(24 \mathrm{~h} ; 20 \mu \mathrm{g} / \mathrm{mL})$ to induce oxidative stress and inflammatory-like conditions, respectively, damaged tight junctions $(\mathrm{D}, \mathrm{G})$, while incubation with N and ND treatments during the last hour of the induction recovered the altered structure $(\mathbf{E}, \mathbf{F}, \mathbf{H}, \mathbf{I})$. Nuclei were labelled with DAPI (blue). Scale bar: $20 \mu \mathrm{m}$. 


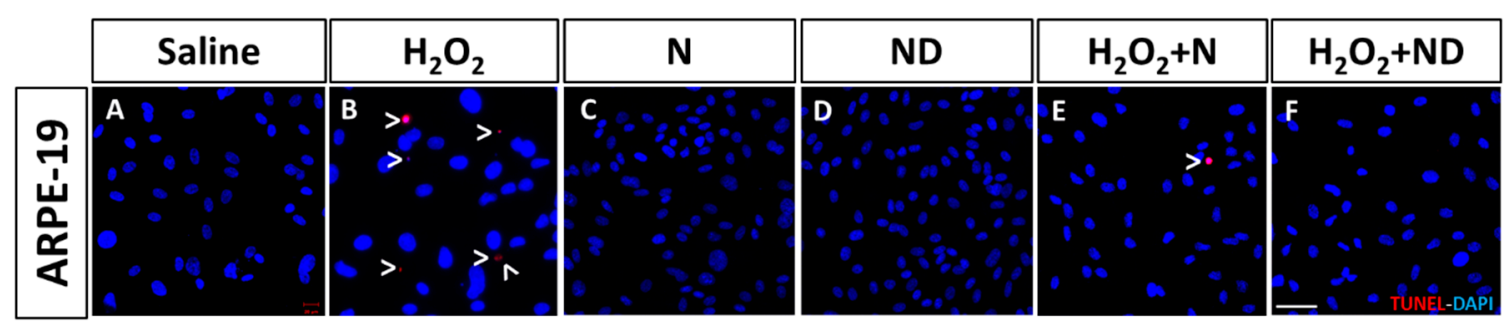

\section{G}

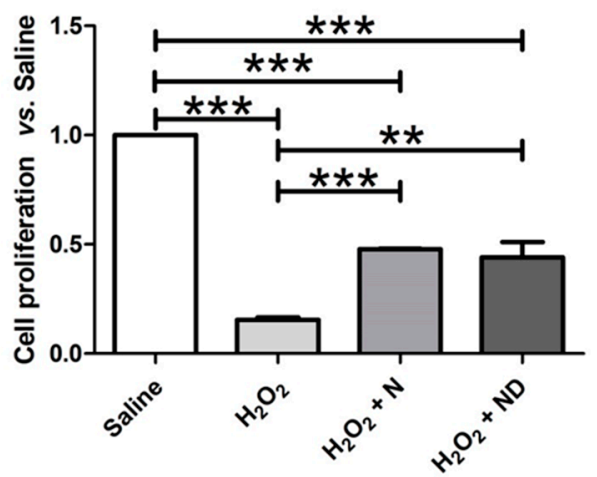

H

HREC BrdU

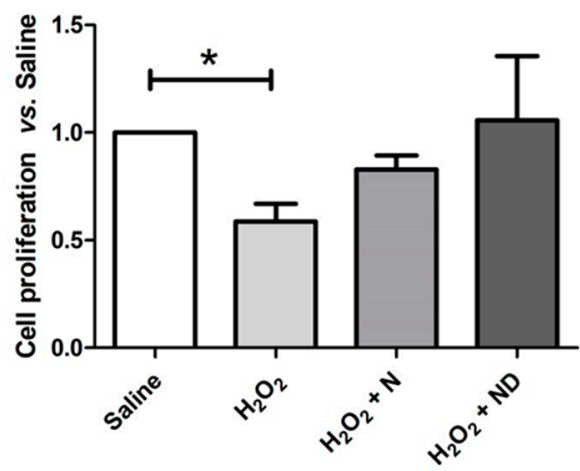

Figure 2. Late apoptosis assessed in ARPE-19 cells by TUNEL labelling and imaged under a confocal microscope. Application of $\mathrm{N}$ and $\mathrm{ND}$ treatments $(62.34 \mu \mathrm{g} / \mathrm{mL})$ to the media $(\mathbf{C}, \mathbf{D})$ showed similar results to saline (A). Addition of $\mathrm{H}_{2} \mathrm{O}_{2}(2 \mathrm{~h}$; $600 \mu \mathrm{M}$ ) to induce oxidative stress increased TUNEL-positive-stained ARPE-19 cells (B; red), while TUNEL labelling was absent by application of $\mathrm{N}$ and ND treatments $(62.34 \mu \mathrm{g} / \mathrm{mL}$ each) during the last hour of the induction (E,F). Nuclei were labelled with DAPI (blue). Scale bar: $50 \mu \mathrm{m}$. Cell proliferation assay was performed in both ARPE-19 and HREC cells (G,H), $n=3$. BrdU expression levels were significantly reduced in both cell lines following oxidative stress-induced conditions by $1000 \mu \mathrm{M} \mathrm{H}_{2} \mathrm{O}_{2}$ for $2 \mathrm{~h}$. This effect was significantly recovered in ARPE-19 cells by application of $\mathrm{N}(p<0.001)$ and ND $(p<0.01)$ treatments $(62.34 \mu \mathrm{g} / \mathrm{mL}$ each) during the last hour of the induction, while a strong tendency towards significance was observed in HREC cells $\left({ }^{*} p<0.05,{ }^{* *} p<0.001,{ }^{* * *} p<0.001\right)$.

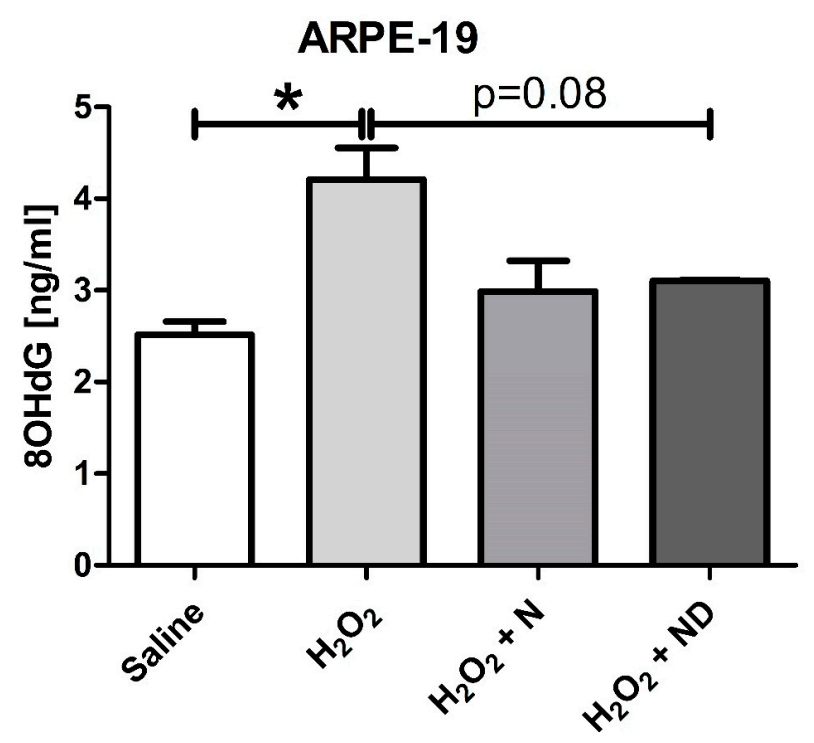

Figure 3. Oxidative damage to DNA was analyzed by $8 \mathrm{OHdG}$ expression levels for ARPE-19 cells measured by ELISA $(n=3)$. Addition of $\mathrm{H}_{2} \mathrm{O}_{2}(2 \mathrm{~h} ; 1000 \mu \mathrm{M})$ to induce oxidative stress conditions significantly $(p<0.05)$ increased 8 OHdG levels. Application of $\mathrm{N}$ and ND treatments $(62.34 \mu \mathrm{g} / \mathrm{mL}$ each) during the last hour of the induction time were able to reduce $8 \mathrm{OHdG}$ levels in the media, but not to significant levels $(p=0.08) .\left({ }^{*} p<0.05\right)$. 
A
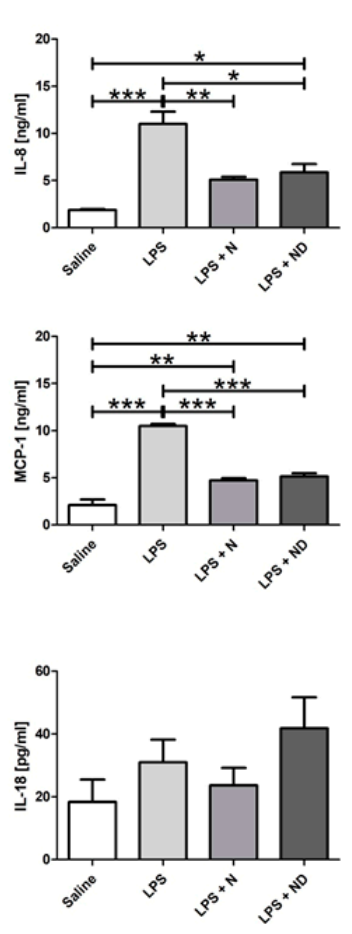

B
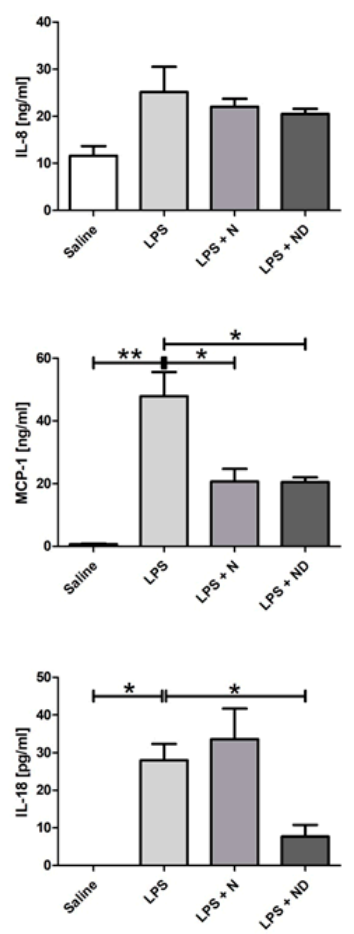

ARPE-19
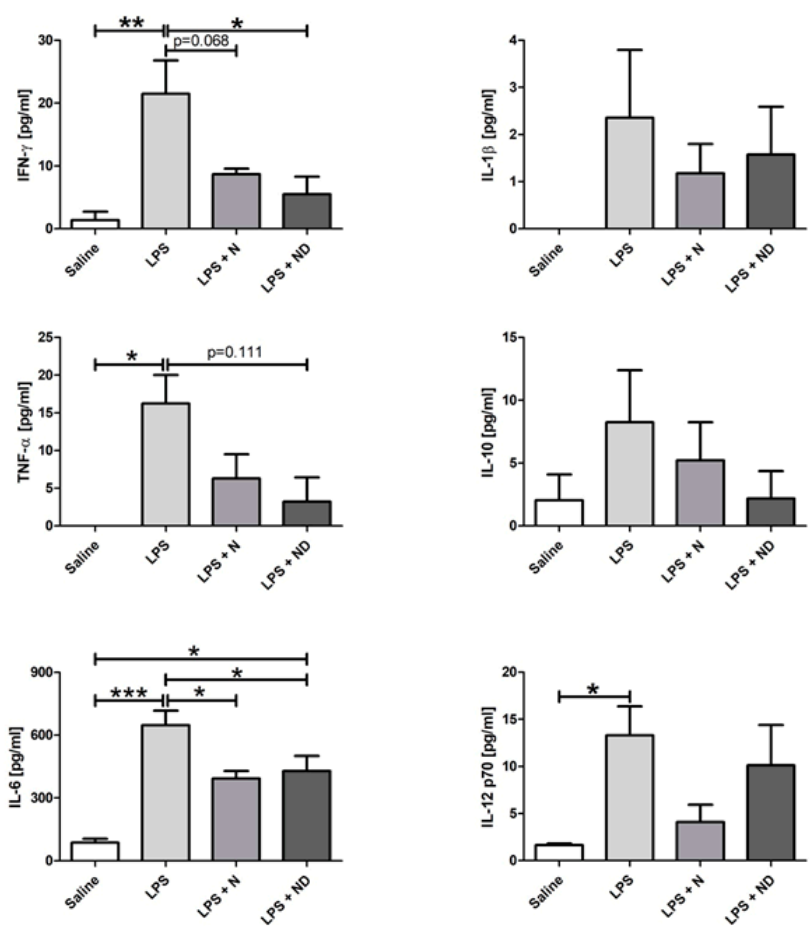

HREC
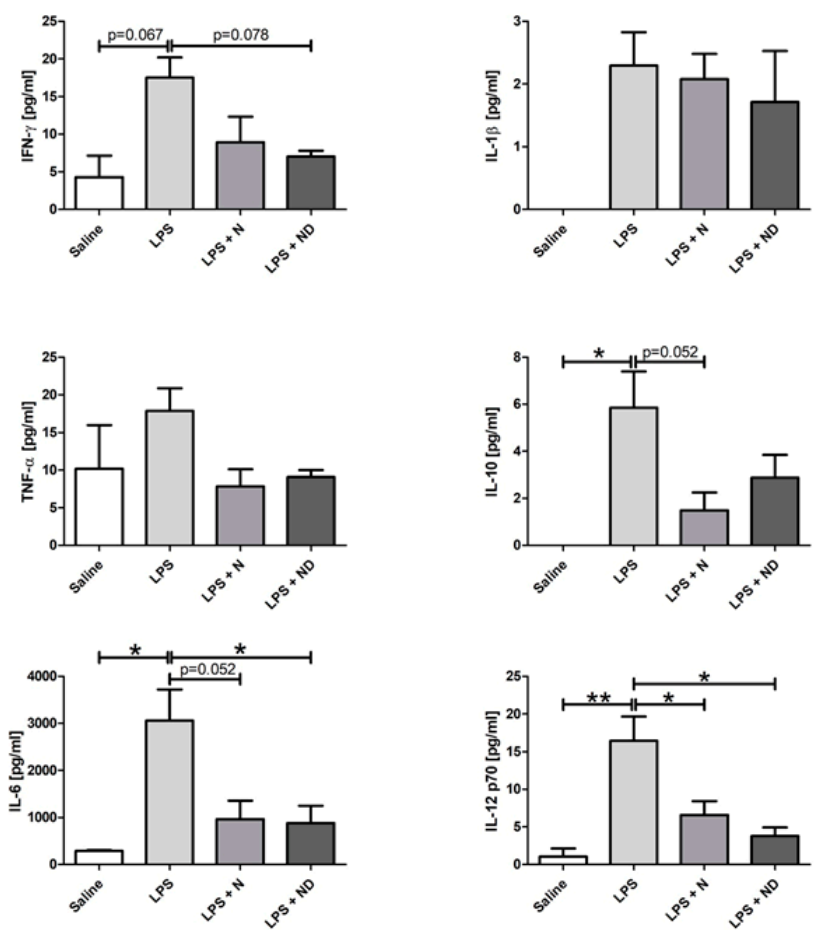

Figure 4. Multiple cytokine expression assays in ARPE-19 and HREC cells $(n=3)$. (A) Expression levels of IL-8, MCP-1, TNF- $\alpha$, IFN $\gamma$, IL-6, and IL-12p70 were significantly increased $(p<0.05)$ following addition of LPS $(24 \mathrm{~h} ; 20 \mu \mathrm{g} / \mathrm{mL})$ to induce inflammatory-like conditions in ARPE cells. IL-8, MCP-1, and IL-6 expression levels were significantly reduced $(p<0.05)$ following application of $\mathrm{N}$ and ND $(62.34 \mu \mathrm{g} / \mathrm{mL}$ each) during the last hour of the induction time. Addition of ND in LPS-induced media was able to significantly decrease $(p<0.05)$ the expression levels of IFN $\gamma$ and 
attenuate the expression of TNF $\alpha(p=0.111)$, while N showed a strong tendency to reduce IFN$\gamma(p=0.068)$. (B) Expression levels of MCP-1, IL-10, IL-18, IL-6, and IL-12p70 were significantly increased $(p<0.05)$ after addition of LPS to induce inflammatory-like conditions $(24 \mathrm{~h} ; 50 \mu \mathrm{g} / \mathrm{mL})$ in HREC cells. Expression levels of MCP-1 and IL-12p70 were significantly reduced $(p<0.05)$ following application of $\mathrm{N}$ and ND $(62.34 \mu \mathrm{g} / \mathrm{mL}$ each) during the last hour of the induction time. Addition of ND, and not N, in LPS-induced media significantly decreased IL-6 and IL-18 expression levels $(p<0.05)$, while there was a tendency to downregulate $\operatorname{IFN} \gamma(p=0.078)$. Addition of $\mathrm{N}$ attenuated expression of IL-6 and IL-10 ( $p=0.052)$. All cytokines are expressed in pg/mL except for MCP-1 and IL-8 that were expressed as ng/mL. $\left.{ }^{*} p<0.05,{ }^{* *} p<0.001,{ }^{* * *} p<0.001\right)$.

HREC cells subjected to LPS-induced inflammatory-like conditions showed a significant $(p<0.05)$ increase in the expression levels of MCP-1, IL-10, IL-18, IL-6, and IL-12p70 cytokines. Addition of either N or ND to LPS-induced media significantly $(p<0.05)$ attenuated expression levels of MCP-1 and IL-12p70. The expression levels of IL-6 and IL-18 were significantly reduced $(p<0.05)$ only after addition of ND and not N in LPS-induced cells. IFN $\gamma$ expression levels revealed a tendency to increase $(p=0.067)$ after LPS addition, while application of ND treatment showed a tendency to downregulate the cytokine $(p=0.078)$. Interestingly, addition of $\mathrm{N}$ treatment to inflammatory-induced HREC cells had a strong tendency to decrease the expression levels of IL-10 and IL-6 $(p=0.052)$.

In our experiment, we noticed that the expression levels of few cytokines, in both ARPE-19 and HREC cells, under LPS-induced inflammatory conditions were not increased, and there was no significant difference with saline. A plausible reason could be the dispersion of controls in our study. In addition, absence of regulation of those proteins by LPS at the studied concentration could provide information on the expression pathway for each cell type.

\section{Discussion}

This study demonstrates that the oxidative and inflammatory-induced damage was reversed in ARPE-19 and HREC cell lines by adding either a nutritional antioxidant complex $(\mathrm{N})$ or the complex in combination with vitamin D (ND). In some circumstances, ND appeared to have had a more potent effect than $\mathrm{N}$ alone, suggesting a possible synergistic role between the supplement and vitamin $\mathrm{D}$.

Specifically, ARPE-19 cells, in response to oxidative stress or inflammation, induced by the addition of $\mathrm{H}_{2} \mathrm{O}_{2}$ or LPS, revealed partial loss and damage of their junctional integrity. This is in line with previous studies whereby exposure of ARPE-19 cells to the same stress inducers resulted in reduced expression of ZO-1 protein, more disorganized tight junctions with breaks in peripheral staining [36,44,45]. Additionally, our results demonstrated that application of $\mathrm{N}$ and ND to the media counteracted these morphological changes. Earlier investigations demonstrated that vitamin $\mathrm{D}$ restored damaged tight junctions and increased ZO-1 protein levels in ARPE-19 cells under oxidative stress conditions [36,46], which suggests its role in blood-retinal barrier integrity through intercellular adherent junctions [47].

8-OHdG is a major product of oxidative DNA damage [48] that is associated with AMD [49-51] and was used in our study as an additional oxidative stress marker to further confirm the antioxidant effect of vitamin D and the nutritional complex. A recent study has described a negative correlation between an aging suppressor protein in mammals, klotho, with 8-OHdG expression levels in aqueous humor of patients with exudative AMD [51]. This suggests that the reduced antioxidant defense response by the attenuated expression levels of klotho result in enhanced oxidative stress and consequently to AMD pathogenesis. The elevated 8-OHdG levels observed in ARPE-19 cells after $\mathrm{H}_{2} \mathrm{O}_{2}$-induced oxidative stress were reduced following addition of either N or ND to the media. Deficiency of vitamin $\mathrm{D}$ has been described to be associated with higher oxidation-induced DNA damage in diabetic retinopathy [52], a retinal disorder associated with diabetes mellitus [53], and supplementation with vitamin $\mathrm{D}$ had a beneficial impact on oxidative stress by reducing 8-OHdG concentrations in patients with type 2 diabetes [54]. Investigators have 
also demonstrated that elevated 8-OHdG levels in ARPE-19 cells under $\mathrm{H}_{2} \mathrm{O}_{2}$ oxidative stress-induced conditions were significantly reduced by application of vitamin $\mathrm{D}$ to the media [36]. Therefore, vitamin D may participate in antioxidant-related mechanisms to decrease oxidative stress by scavenging reactive oxygen species whose production in the retina result in mitochondrial and nuclear DNA damage as described for RPE in AMD patients [50]. In addition, the role of vitamin D in oxidative stress reduction was described in mouse cone cells against photoreceptor degeneration [55] and in studies involving upregulated expression of antioxidant genes (glutathione peroxidase GPX2 and GPX3; superoxide dismutase SOD1 and SOD2; catalase, CAT) [35].

Reactive oxygen species production can activate apoptosis signaling pathways [56], and antioxidants are able to suppress apoptosis [57]. Earlier studies have shown that $\mathrm{H}_{2} \mathrm{O}_{2}$, LPS, or high-glucose-induced oxidative damage enhance apoptosis in RPE and retinal endothelial cells $[35,58-61]$, which was reduced following application of vitamin D in ARPE-19 cells $[35,36,60]$ and retinal endothelial cells $[36,61]$, respectively. This is consistent with our results, where we observed that $\mathrm{H}_{2} \mathrm{O}_{2}$ resulted in enhanced apoptosis in ARPE-19 cells, which was counteracted by the addition of either N or ND treatments to the media. In addition, our results demonstrate significant reduction in cell proliferation after addition of $\mathrm{H}_{2} \mathrm{O}_{2}$ in both cell lines, characterized by subsequent recovery following application of either N or ND to the media, with ND presenting a more potent effect than $\mathrm{N}$ in HREC cells. Earlier studies have effectively described the vital role of oxidative stress by $\mathrm{H}_{2} \mathrm{O}_{2}$ in inhibiting cell proliferation in various cells [62], including RPE in the retina $[35,46,63,64]$. The exact mechanisms have not been identified, however, recent studies have revealed the interference of $\mathrm{H}_{2} \mathrm{O}_{2}$ in numerous intracellular signaling pathways in retinal epithelial cells, such as the epidermal growth factor receptor/AKT and Notch signaling pathways [46,64], including the regulation of autophagy [65], kinases, and proapoptotic proteins such as caspases [66-68]. These studies open the way towards future identification of the mechanisms involved in the interplay between vitamin $\mathrm{D}$ and retinal cells in restoring cell proliferation and protecting RPE from angiogenesis.

Overall, the results above suggest that vitamin D possibly provides an additional protective effect to the nutritional antioxidant complex in RPE cell viability and the bloodretina barrier from chronic oxidative stress and apoptosis, which lead to retinal pathologies, including AMD.

In the present study, besides oxidative stress, we investigated the potential role of vitamin $\mathrm{D}$ and the nutritional antioxidant complex in the downregulation of inflammatory cytokines under LPS-induced inflammatory conditions.

Inflammatory mediators, such as IL-1 $\beta$, IL-6, IL-8, IL-10, IL-18, IL-12p70, TNF $\alpha$, IFN $\gamma$, and MCP-1, play a vital role in the development of AMD and have angiogenic properties [69-78], and their activity is upregulated following addition of LPS [36] or $\mathrm{H}_{2} \mathrm{O}_{2}$ [35] to the media.

Consistent with our observations, earlier studies have reported downregulation of IL-8, IL-6, MCP1, IFN $\gamma$, and TNF $\alpha$ in ARPE-19 cells $[35,36,79,80]$ and reduced expression levels of MCP-1, IL-12p70, IL-18, IL-6, and IFN $\gamma$ in HREC cells [36] following vitamin $\mathrm{D}$ administration to the media. Our results indicate that ND treatment more effectively downregulates the expression levels of IL-18, IL-6, and IFN $\gamma$ in HREC cells and of IFN $\gamma$ and TNF $\alpha$ in ARPE-19 cells under LPS-induced inflammation. Therefore, vitamin D potentially has a synergistic effect with the nutritional antioxidant complex in regulating cytokine expression levels. This further suggests future elucidation of understanding the critical molecular interactions between vitamin $\mathrm{D}$ and nutritional complex components in combination with the corresponding cytokines and intracellular signaling transduction pathways involved in potentially preventing progression to neovascular AMD.

The observed downregulation of IL-18 and IL-12p70 upon addition of vitamin D under LPS-induced inflammatory conditions only in HREC cells and not in RPE cells suggests an anti-angiogenic role through regulation of vascular endothelial growth factor (VEGF) production. This is consistent with an earlier study where IL-18-neutralizing antibodies 
were intravitreally injected in a laser-induced choroidal neovascularization (CNV) mouse model, and CNV development increased compared to non-injected mice [81]. However, the anti-angiogenic effect of IL-18 is not clear, and further investigation is required since other studies show that intravitreal injections of IL-18 in CNV mouse, and transfection of plasmids encoding IL-18 into RPE cells via injection in mice, had no effect on CNV volume [82].

The pro-inflammatory cytokine IL-12 enhances production of IFN $\gamma$ through activation of the JAK/STAT signaling pathway [83], which along with TNF $\alpha$ and IL-1 $\beta$ lead to enhanced production of VEGF and IL-6 [77], whereby all of these mediators are implicated in phagocytosis, visual cycle, and epithelial morphology in RPE cells [70], as well as in the complement pathway, angiogenesis, and matrix remodeling [69]. Therefore, the observed downregulation of IL-8, IL-18, IL-12p70, and MCP-1 by vitamin D may potentially reduce the concentration of macrophages, microglia, and lymphocytes in the retina and inhibit migration and proliferation of endothelial cells that play a key role in angiogenesis $[77,84]$.

Vitamin D has been shown to stimulate the expression of the potent anti-inflammatory cytokine IL-10 [85,86], which inhibits the production of the proinflammatory IL-12 through nuclear factor $\mathrm{\kappa B}(\mathrm{Nf} \kappa \mathrm{B})$ and activator protein 1 (AP1) [83], and of certain other proinflammatory cytokines, such as IL-1, IL-6, IL-8, and TNF $\alpha[32,83,86,87]$. The anti-inflammatory role of IL-10 has been shown in a CNV mouse model, where IL-10 deficiency increased inflammation and subsequent intraocular injection enhanced the volume of neovascularization [88]. Similarly, IL-10 increased the secretion of the proinflammatory cytokine IL-6 through regulation of VEGF production and is implicated in the prevention of the development of rhematogeneous retinal detachment [89]. Interestingly, our results are consistent with a recent study [36], revealing that the elevated IL-10 expression levels under LPS-induced inflammatory conditions remained unmodified after application of either $\mathrm{N}$ or ND in both cell lines, thus suggesting a protective role of vitamin D against inflammation. Additionally, the IL-10 downregulation, after addition of ND under inflammatory-induced conditions, was higher in ARPE-19 than HREC cells, supporting a potential anti-angiogenic role through a synergistic effect between the nutritional antioxidant complex and vitamin $D$ by inducing IL-10, which in turn is involved in a dynamic modulation of pro-inflammatory cytokines and transcription factors.

This interplay of molecular interactions and involvement of various signaling pathways requires deeper investigation while considering the involvement of other cytokine mediators not mentioned in this study. For instance, vitamin $\mathrm{D}$ has been recently shown to recover expression levels of IL-33 in ARPE-19 cells after $\mathrm{H}_{2} \mathrm{O}_{2}$ addition, which stimulated expression of antioxidant genes [35], suggesting a key role of this cytokine in AMD since it was also shown to inhibit murine CNV [90] and to reduce retinal inflammation [91].

One limitation of this study involves the experimentation on immortalized cell lines, and thus we recommend future investigation on primary cell lines and subsequently in in vivo models of AMD and clinical trials. This will enable us to take into consideration other molecules, such as natural nutritional components, vitamins, and minerals, that may also provide an additional benefit in combination with vitamin $\mathrm{D}$.

Additional future studies could examine modulation of matrix metalloproteinases (MMPs) and VEGF/PEDF by N and ND under oxidative stress-induced conditions. MMP activity in RPE affects the ECM and subsequently the thickness of Bruch membrane, which may induce release/activation of angiogenic factors that are vital to angiogenesis, such as VEGF/PEDF, from choroidal endothelial cells. Therefore, endothelial cells in the choroid could be investigated since different cell types may respond differently to N and/or ND under oxidative or inflammatory stress-induced conditions and may involve different signal transduction mechanisms. This will further enable us to evaluate the signaling events among the cells in the RPE, the retina, and the choroid, and thus further elucidate retinal homeostasis. 


\section{Conclusions}

Our results demonstrate that upon oxidative stress and inflammation-induced conditions, cell proliferation is reduced, junctional integrity is weakened, oxidative DNA damage and apoptosis are enhanced, and expression levels of inflammatory cytokines are increased. Nevertheless, application of vitamin D together with the nutritional antioxidant complex to the media counteract these changes with ND, exhibiting in some cases a more potent protective role than $\mathrm{N}$ alone, suggesting the possible existence of a synergistic effect between the nutritional antioxidant complex and vitamin $\mathrm{D}$ towards a more efficient oral supplementation treatment for the early stage of AMD.

Supplementary Materials: The following are available online at https:/ /www.mdpi.com/article/10 .3390/nu13051423/s1, Figure S1: ARPE-19 and HREC cells' phenotyping. Figure S2: MTT assay in ARPE-19 and HREC cells. Table S1: Composition of Nutrof Total ${ }^{\circledR}$ used in the study (per one capsule).

Author Contributions: Conceptualization, P.F.-R., S.R., M.H. and A.G.-L.; data curation, J.B.; funding acquisition, P.F.-R. and A.G.-L.; investigation, S.R., M.M.-O., I.B. and J.B.-B.; methodology, S.R., M.S.d.V. and M.H.; project administration, P.F.-R.; supervision, P.F.-R., S.R. and M.H.; writingoriginal draft, P.F.-R. and M.H.; writing-review and editing, P.F.-R., S.R., M.S.d.V., M.H., J.G.-Z., V.B.M., J.B.-B. and A.G.-L. All authors have read and agreed to the published version of the manuscript.

Funding: This study has been sponsored by Thea Laboratories (Clermont-Ferrand, France). The funding sponsors had no role in the interpretation of data or the writing of the manuscript.

Institutional Review Board Statement: Not applicable.

Informed Consent Statement: Not applicable.

Data Availability Statement: All data are available within the manuscript and upon request to corresponding authors.

Acknowledgments: This study has been sponsored by Thea Laboratories (Clermont-Ferrand, France). We greatly appreciate the expertise and assistance of Creative Pharma Services S.M.S.A. for their help in editing, writing, and revising the manuscript.

Conflicts of Interest: A.G.-L. is consultant for Bayer, Novartis, Allergan, Thea, and Roche. The rest of the authors declare no conflict of interest. The funders had no role in the design of the study; in the collection, analyses, or interpretation of data; in the writing of the manuscript; or in the decision to publish the results.

\section{References}

1. Lim, L.S.; Mitchell, P.; Seddon, J.M.; Holz, F.G.; Wong, T.Y. Age-related macular degeneration. Lancet 2012, 379, 1728-1738. [CrossRef]

2. Gheorghe, A.; Mahdi, L.; Musat, O. Age-related macular degeneration. Rom. J. Ophthalmol. 2015, 59, 74-77. [PubMed]

3. Mitchell, P.; Liew, G.; Gopinath, B.; Wong, T.Y. Age-related macular degeneration. Lancet 2018, 392, 1147-1159. [CrossRef]

4. Klein, R.; Cruickshanks, K.J.; Nash, S.D.; Krantz, E.M.; Nieto, F.J.; Huang, G.H.; Pankow, J.S.; Klein, B.E. The prevalence of age-related macular degeneration and associated risk factors. Arch. Ophthalmol. 2010, 128, 750-758. [CrossRef] [PubMed]

5. Ferris, F.L., 3rd; Wilkinson, C.P.; Bird, A.; Chakravarthy, U.; Chew, E.; Csaky, K.; Sadda, S.R. Clinical classification of age-related macular degeneration. Ophthalmology 2013, 120, 844-851. [CrossRef]

6. Taylor, H.R.; West, S.; Muñoz, B.; Rosenthal, F.S.; Bressler, S.B.; Bressler, N.M. The long-term effects of visible light on the eye. Arch. Ophthalmol. 1992, 110, 99-104. [CrossRef]

7. Mitchell, P.; Wang, J.J.; Smith, W.; Leeder, S.R. Smoking and the 5-year incidence of age-related maculopathy: The Blue Mountains Eye Study. Arch. Ophthalmol. 2002, 120, 1357-1363. [CrossRef]

8. Klein, R.; Peto, T.; Bird, A.; Vannewkirk, M.R. The epidemiology of age-related macular degeneration. Am. J. Ophthalmol. 2004, 137, 486-495. [CrossRef]

9. Klein, M.L.; Mauldin, W.M.; Stoumbos, V.D. Heredity and age-related macular degeneration. Observations in monozygotic twins. Arch. Ophthalmol. 1994, 112, 932-937. [CrossRef]

10. Mares-Perlman, J.A.; Brady, W.E.; Klein, R.; VandenLangenberg, G.M.; Klein, B.E.; Palta, M. Dietary fat and age-related maculopathy. Arch. Ophthalmol. 1995, 113, 743-748. [CrossRef]

11. Mares-Perlman, J.A.; Millen, A.E.; Ficek, T.L.; Hankinson, S.E. The body of evidence to support a protective role for lutein and zeaxanthin in delaying chronic disease. Overview. J. Nutr. 2002, 132, 518s-524s. [CrossRef] 
12. Mares, J. Carotenoids and eye disease: Epidemiological evidence. In Krinsky NI Mayne ST Sies Heds. Carotenoids in Health and Disease; Marcel Dekker Inc.: New York, NY, USA, 2004.

13. Seddon, J.M.; Rosner, B.; Sperduto, R.D.; Yannuzzi, L.; Haller, J.A.; Blair, N.P.; Willett, W. Dietary fat and risk for advanced age-related macular degeneration. Arch. Ophthalmol. 2001, 119, 1191-1199. [CrossRef] [PubMed]

14. Beatty, S.; Koh, H.; Phil, M.; Henson, D.; Boulton, M. The role of oxidative stress in the pathogenesis of age-related macular degeneration. Surv. Ophthalmol. 2000, 45, 115-134. [CrossRef]

15. Khandhadia, S.; Lotery, A. Oxidation and age-related macular degeneration: Insights from molecular biology. Expert Rev. Mol. Med. 2010, 12, e34. [CrossRef] [PubMed]

16. Layana, A.G.; Minnella, A.M.; Garhöfer, G.; Aslam, T.; Holz, F.G.; Leys, A.; Silva, R.; Delcourt, C.; Souied, E.; Seddon, J.M. Vitamin D and Age-Related Macular Degeneration. Nutrients 2017, 9, 1120. [CrossRef] [PubMed]

17. Alizadeh, E.; Mammadzada, P.; André, H. The Different Facades of Retinal and Choroidal Endothelial Cells in Response to Hypoxia. Int. J. Mol. Sci. 2018, 19, 3846. [CrossRef]

18. Carmeliet, P.; De Smet, F.; Loges, S.; Mazzone, M. Branching morphogenesis and antiangiogenesis candidates: Tip cells lead the way. Nat. Rev. Clin. Oncol. 2009, 6, 315-326. [CrossRef] [PubMed]

19. A randomized, placebo-controlled, clinical trial of high-dose supplementation with vitamins $C$ and $E$, beta carotene, and zinc for age-related macular degeneration and vision loss: AREDS report no. 8. Arch. Ophthalmol. 2001, 119, 1417-1436. [CrossRef]

20. Lutein + zeaxanthin and omega-3 fatty acids for age-related macular degeneration: The Age-Related Eye Disease Study 2 (AREDS2) randomized clinical trial. JAMA 2013, 309, 2005-2015. [CrossRef]

21. Parekh, N.; Chappell, R.J.; Millen, A.E.; Albert, D.M.; Mares, J.A. Association between vitamin D and age-related macular degeneration in the Third National Health and Nutrition Examination Survey, 1988 through 1994. Arch. Ophthalmol. 2007, 125, 661-669. [CrossRef]

22. Albert, D.M.; Scheef, E.A.; Wang, S.; Mehraein, F.; Darjatmoko, S.R.; Sorenson, C.M.; Sheibani, N. Calcitriol is a potent inhibitor of retinal neovascularization. Investig. Ophthalmol. Vis. Sci. 2007, 48, 2327-2334. [CrossRef]

23. Annweiler, C.; Drouet, M.; Duval, G.T.; Paré, P.Y.; Leruez, S.; Dinomais, M.; Milea, D. Circulating vitamin D concentration and age-related macular degeneration: Systematic review and meta-analysis. Maturitas 2016, 88, 101-112. [CrossRef]

24. Merle, B.M.J.; Silver, R.E.; Rosner, B.; Seddon, J.M. Associations Between Vitamin D Intake and Progression to Incident Advanced Age-Related Macular Degeneration. Investig. Ophthalmol. Vis. Sci. 2017, 58, 4569-4578. [CrossRef] [PubMed]

25. Kan, E.; Kan, E.K.; Yücel, Ö.E. The Possible Link Between Vitamin D Levels and Exudative Age-related Macular Degeneration. Oman. Med. J. 2020, 35, e83. [CrossRef]

26. Millen, A.E.; Nie, J.; Mares, J.A.; Lutsey, P.L.; LaMonte, M.J.; Meuer, S.M.; Sahli, M.W.; Andrews, C.A.; Klein, B.E.K.; Klein, R. Serum 25-Hydroxyvitamin D Concentrations and Incidence of Age-Related Macular Degeneration: The Atherosclerosis Risk in Communities Study. Investig. Ophthalmol. Vis. Sci. 2019, 60, 1362-1371. [CrossRef]

27. Millen, A.E.; Nie, J.; Sahli, M.W.; Mares, J.A.; Meyers, K.J.; Klein, B.E.K.; LaMonte, M.J.; Lutsey, P.L.; Andrews, C.A.; Klein R. Vitamin D Status and Prevalent Early Age-Related Macular Degeneration in African Americans and Caucasians: The Atherosclerosis Risk in Communities (ARIC) Study. J. Nutr. Health Aging 2017, 21, 772-780. [CrossRef]

28. Aoki, A.; Inoue, M.; Nguyen, E.; Obata, R.; Kadonosono, K.; Shinkai, S.; Hashimoto, H.; Sasaki, S.; Yanagi, Y. Dietary n-3 Fatty Acid, $\alpha$-Tocopherol, Zinc, vitamin D, vitamin C, and $\beta$-carotene are Associated with Age-Related Macular Degeneration in Japan. Sci. Rep. 2016, 6, 20723. [CrossRef]

29. Bae, S.H.; Shin, Y.J.; Kim, H.K.; Hyon, J.Y.; Wee, W.R.; Park, S.G. Vitamin D Supplementation for Patients with Dry Eye Syndrome Refractory to Conventional Treatment. Sci. Rep. 2016, 6, 33083. [CrossRef] [PubMed]

30. Karaca, E.E.; Kemer, Ö.E.; Özek, D.; Berker, D.; Imga, N.N. Clinical outcomes of ocular surface in patients treated with vitamin D oral replacement. Arq. Bras. Oftalmol. 2020, 83, 312-317. [CrossRef] [PubMed]

31. Alsalem, J.A.; Patel, D.; Susarla, R.; Coca-Prados, M.; Bland, R.; Walker, E.A.; Rauz, S.; Wallace, G.R. Characterization of vitamin D production by human ocular barrier cells. Investig. Ophthalmol. Vis. Sci. 2014, 55, 2140-2147. [CrossRef] [PubMed]

32. Reins, R.Y.; McDermott, A.M. Vitamin D: Implications for ocular disease and therapeutic potential. Exp. Eye Res. 2015, 134, 101-110. [CrossRef] [PubMed]

33. Dwyer, M.A.; Kazmin, D.; Hu, P.; McDonnell, D.P.; Malek, G. Research resource: Nuclear receptor atlas of human retinal pigment epithelial cells: Potential relevance to age-related macular degeneration. Mol. Endocrinol. 2011, 25, 360-372. [CrossRef] [PubMed]

34. Jamali, N.; Sorenson, C.M.; Sheibani, N. Vitamin D and regulation of vascular cell function. Am. J. Physiol. Heart Circ. Physiol. 2018, 314, H753-H765. [CrossRef] [PubMed]

35. Tohari, A.M.; Alhasani, R.H.; Biswas, L.; Patnaik, S.R.; Reilly, J.; Zeng, Z.; Shu, X. Vitamin D Attenuates Oxidative Damage and Inflammation in Retinal Pigment Epithelial Cells. Antioxidants 2019, 8, 341. [CrossRef]

36. Fernandez-Robredo, P.; González-Zamora, J.; Recalde, S.; Bilbao-Malavé, V.; Bezunartea, J.; Hernandez, M.; Garcia-Layana, A Vitamin D Protects against Oxidative Stress and Inflammation in Human Retinal Cells. Antioxidants 2020, 9, 838. [CrossRef] [PubMed]

37. Johnson, J.A.; Grande, J.P.; Roche, P.C.; Campbell, R.J.; Kumar, R. Immuno-localization of the calcitriol receptor, calbindin-D28k and the plasma membrane calcium pump in the human eye. Curr. Eye Res. 1995, 14, 101-108. [CrossRef] 
38. Morrison, M.A.; Silveira, A.C.; Huynh, N.; Jun, G.; Smith, S.E.; Zacharaki, F.; Sato, H.; Loomis, S.; Andreoli, M.T.; Adams, S.M.; et al. Systems biology-based analysis implicates a novel role for vitamin D metabolism in the pathogenesis of age-related macular degeneration. Hum. Genom. 2011, 5, 538-568. [CrossRef]

39. Millen, A.E.; Voland, R.; Sondel, S.A.; Parekh, N.; Horst, R.L.; Wallace, R.B.; Hageman, G.S.; Chappell, R.; Blodi, B.A.; Klein, M.L.; et al. Vitamin D status and early age-related macular degeneration in postmenopausal women. Arch. Ophthalmol. 2011, 129, 481-489. [CrossRef]

40. Golan, S.; Shalev, V.; Treister, G.; Chodick, G.; Loewenstein, A. Reconsidering the connection between vitamin D levels and age-related macular degeneration. Eye (London) 2011, 25, 1122-1129. [CrossRef]

41. Day, S.; Acquah, K.; Platt, A.; Lee, P.P.; Mruthyunjaya, P.; Sloan, F.A. Association of vitamin D deficiency and age-related macular degeneration in medicare beneficiaries. Arch. Ophthalmol. 2012, 130, 1070-1071. [CrossRef]

42. Cougnard-Grégoire, A.; Merle, B.M.; Korobelnik, J.F.; Rougier, M.B.; Delyfer, M.N.; Féart, C.; Le Goff, M.; Dartigues, J.F.; Barberger-Gateau, P.; Delcourt, C. Vitamin D Deficiency in Community-Dwelling Elderly Is Not Associated with Age-Related Macular Degeneration. J. Nutr. 2015, 145, 1865-1872. [CrossRef] [PubMed]

43. Kim, E.C.; Han, K.; Jee, D. Inverse relationship between high blood 25-hydroxyvitamin D and late stage of age-related macular degeneration in a representative Korean population. Investig. Ophthalmol. Vis. Sci. 2014, 55, 4823-4831. [CrossRef] [PubMed]

44. Bailey, T.A.; Kanuga, N.; Romero, I.A.; Greenwood, J.; Luthert, P.J.; Cheetham, M.E. Oxidative stress affects the junctional integrity of retinal pigment epithelial cells. Investig. Ophthalmol. Vis. Sci. 2004, 45, 675-684. [CrossRef] [PubMed]

45. Zou, X.L.; Wang, G.F.; Li, D.D.; Chen, J.X.; Zhang, C.L.; Yu, Y.Z.; Zhou, W.J.; Zou, Y.P.; Rao, B.Q. Protection of tight junction between RPE cells with tissue factor targeting peptide. Int. J. Ophthalmol. 2018, 11, 1594-1599. [CrossRef] [PubMed]

46. Murugeswari, P.; Firoz, A.; Murali, S.; Vinekar, A.; Krishna, L.; Anandula, V.R.; Jeyabalan, N.; Chevour, P.; Jayadev, C.; Shetty, R.; et al. Vitamin-D3 ( $\alpha-1,25(\mathrm{OH})$ 2D3) Protects Retinal Pigment Epithelium From Hyperoxic Insults. Investig. Ophthalmol. Vis. Sci. 2020, 61, 4. [CrossRef]

47. Marrs, J.A.; Andersson-Fisone, C.; Jeong, M.C.; Cohen-Gould, L.; Zurzolo, C.; Nabi, I.R.; Rodriguez-Boulan, E.; Nelson, W.J. Plasticity in epithelial cell phenotype: Modulation by expression of different cadherin cell adhesion molecules. J. Cell Biol. 1995, 129, 507-519. [CrossRef] [PubMed]

48. Valavanidis, A.; Vlachogianni, T.; Fiotakis, C. 8-hydroxy-2'-deoxyguanosine (8-OHdG): A critical biomarker of oxidative stress and carcinogenesis. J. Environ. Sci. Health C Environ. Carcinog. Ecotoxicol. Rev. 2009, 27, 120-139. [CrossRef]

49. Totan, Y.; Yağci, R.; Bardak, Y.; Ozyurt, H.; Kendir, F.; Yilmaz, G.; Sahin, S.; Sahin Tiğ, U. Oxidative macromolecular damage in age-related macular degeneration. Curr. Eye Res. 2009, 34, 1089-1093. [CrossRef]

50. Abokyi, S.; To, C.H.; Lam, T.T.; Tse, D.Y. Central Role of Oxidative Stress in Age-Related Macular Degeneration: Evidence from a Review of the Molecular Mechanisms and Animal Models. Oxid. Med. Cell Longev. 2020, 2020, 7901270. [CrossRef]

51. Ma, Z.; Liu, J.; Li, J.; Jiang, H.; Kong, J. Klotho Levels are Decreased and Associated with Enhanced Oxidative Stress and Inflammation in the Aqueous Humor in Patients with Exudative Age-related Macular Degeneration. Ocul. Immunol. Inflamm. 2020, 1-8. [CrossRef]

52. Longo-Mbenza, B.; Mvitu Muaka, M.; Masamba, W.; Muizila Kini, L.; Longo Phemba, I.; Kibokela Ndembe, D.; Tulomba Mona, D. Retinopathy in non diabetics, diabetic retinopathy and oxidative stress: A new phenotype in Central Africa? Int. J. Ophthalmol. 2014, 7, 293-301. [CrossRef]

53. Wang, W.; Lo, A.C.Y. Diabetic Retinopathy: Pathophysiology and Treatments. Int. J. Mol. Sci. 2018, 19, 1816. [CrossRef]

54. Damghanian, P.; Javanbakht, M.H.; Mohammadzadeh Honarvar, N.; Yousefirad, E.; Mohammadi, H.; Zarei, M.; Djalalli, M. Effects of Vitamin D supplementation on 8-hydroxydeoxy guanosine and 3-nitrotyrosine in patients with type 2 diabetes: A randomized clinical trial. Prog. Nutr. 2019, 21, 138-146. [CrossRef]

55. Tohari, A.M.; Zhou, X.; Shu, X. Protection against oxidative stress by vitamin D in cone cells. Cell Biochem. Funct. 2016, 34, 82-94. [CrossRef] [PubMed]

56. Redza-Dutordoir, M.; Averill-Bates, D.A. Activation of apoptosis signalling pathways by reactive oxygen species. Biochim. Biophys. Acta. 2016, 1863, 2977-2992. [CrossRef] [PubMed]

57. Zeisel, S.H. Antioxidants suppress apoptosis. J. Nutr. 2004, 134, 3179s-3180s. [CrossRef]

58. Jin, G.F.; Hurst, J.S.; Godley, B.F. Hydrogen peroxide stimulates apoptosis in cultured human retinal pigment epithelial cells. Curr. Eye Res. 2001, 22, 165-173. [CrossRef]

59. Wang, Y.; Shen, D.; Wang, V.M.; Yu, C.R.; Wang, R.X.; Tuo, J.; Chan, C.C. Enhanced apoptosis in retinal pigment epithelium under inflammatory stimuli and oxidative stress. Apoptosis 2012, 17, 1144-1155. [CrossRef]

60. Tohari, A.M.; Almarhoun, M.; Alhasani, R.H.; Biswas, L.; Zhou, X.; Reilly, J.; Zeng, Z.; Shu, X. Protection by vitamin D against high-glucose-induced damage in retinal pigment epithelial cells. Exp. Cell Res. 2020, 392, 112023. [CrossRef]

61. Lu, L.; Lu, Q.; Chen, W.; Li, J.; Li, C.; Zheng, Z. Vitamin D(3) Protects against Diabetic Retinopathy by Inhibiting High-GlucoseInduced Activation of the ROS/TXNIP/NLRP3 Inflammasome Pathway. J. Diabetes Res. 2018, 2018, 8193523. [CrossRef]

62. Vilema-Enríquez, G.; Arroyo, A.; Grijalva, M.; Amador-Zafra, R.I.; Camacho, J. Molecular and Cellular Effects of Hydrogen Peroxide on Human Lung Cancer Cells: Potential Therapeutic Implications. Oxid. Med. Cell Longev. 2016, $2016,1908164$. [CrossRef]

63. Aryan, N.; Betts-Obregon, B.S.; Perry, G.; Tsin, A.T. Oxidative Stress Induces Senescence in Cultured RPE Cells. Open Neurol. J. 2016, 10, 83-87. [CrossRef] 
64. Chen, X.D.; Su, M.Y.; Chen, T.T.; Hong, H.Y.; Han, A.D.; Li, W.S. Oxidative stress affects retinal pigment epithelial cell survival through epidermal growth factor receptor/AKT signaling pathway. Int. J. Ophthalmol. 2017, 10, 507-514. [CrossRef] [PubMed]

65. Blasiak, J.; Barszczewska, G.; Gralewska, P.; Kaarniranta, K. Oxidative stress induces mitochondrial dysfunction and autophagy in ARPE-19 cells. Acta. Ophthalmol. 2019, 97. [CrossRef]

66. Antunes, F.; Brito, P.M. Quantitative biology of hydrogen peroxide signaling. Redox Biol. 2017, 13, 1-7. [CrossRef] [PubMed]

67. Groeger, G.; Quiney, C.; Cotter, T.G. Hydrogen peroxide as a cell-survival signaling molecule. Antioxid Redox Signal 2009, 11, 2655-2671. [CrossRef]

68. Marinho, H.S.; Real, C.; Cyrne, L.; Soares, H.; Antunes, F. Hydrogen peroxide sensing, signaling and regulation of transcription factors. Redox Biol. 2014, 2, 535-562. [CrossRef]

69. An, E.; Gordish-Dressman, H.; Hathout, Y. Effect of TNF-alpha on human ARPE-19-secreted proteins. Mol. Vis. 2008, 14, 2292-2303.

70. Kutty, R.K.; Samuel, W.; Boyce, K.; Cherukuri, A.; Duncan, T.; Jaworski, C.; Nagineni, C.N.; Redmond, T.M. Proinflammatory cytokines decrease the expression of genes critical for RPE function. Mol. Vis. 2016, 22, 1156-1168.

71. Zhao, M.; Bai, Y.; Xie, W.; Shi, X.; Li, F.; Yang, F.; Sun, Y.; Huang, L.; Li, X. Interleukin-1ß Level Is Increased in Vitreous of Patients with Neovascular Age-Related Macular Degeneration (nAMD) and Polypoidal Choroidal Vasculopathy (PCV). PLoS ONE 2015, 10, e0125150. [CrossRef]

72. Wooff, Y.; Man, S.M.; Aggio-Bruce, R.; Natoli, R.; Fernando, N. IL-1 Family Members Mediate Cell Death, Inflammation and Angiogenesis in Retinal Degenerative Diseases. Front Immunol. 2019, 10, 1618. [CrossRef] [PubMed]

73. Goverdhan, S.V.; Ennis, S.; Hannan, S.R.; Madhusudhana, K.C.; Cree, A.J.; Luff, A.J.; Lotery, A.J. Interleukin-8 promoter polymorphism -251A/T is a risk factor for age-related macular degeneration. Br J. Ophthalmol. 2008, 92, 537-540. [CrossRef]

74. Yildirim, Z.; Ucgun, N.I.; Yildirim, F.; Sepici-Dincel, A. Choroidal Neovascular Membrane in Age-Related Macular Degeneration is Associated with Increased Interleukin-6. Int. J. Gerontol. 2012, 6, 101-104. [CrossRef]

75. Nassar, K.; Grisanti, S.; Elfar, E.; Lüke, J.; Lüke, M.; Grisanti, S. Serum cytokines as biomarkers for age-related macular degeneration. Graefes Arch. Clin. Exp. Ophthalmol. 2015, 253, 699-704. [CrossRef] [PubMed]

76. Krogh Nielsen, M.; Subhi, Y.; Molbech, C.R.; Falk, M.K.; Nissen, M.H.; Sørensen, T.L. Systemic Levels of Interleukin-6 Correlate With Progression Rate of Geographic Atrophy Secondary to Age-Related Macular Degeneration. Investig. Ophthalmol. Vis. Sci. 2019, 60, 202-208. [CrossRef] [PubMed]

77. Detrick, B.; Hooks, J.J. The RPE Cell and the Immune System. In Retinal Pigment Epithelium in Health and Disease; Klettner, A., Dithmar, S., Eds.; Springer: Cham, Switzerland, 2020.

78. Cascella, R.; Ragazzo, M.; Strafella, C.; Missiroli, F.; Borgiani, P.; Angelucci, F.; Marsella, L.T.; Cusumano, A.; Novelli, G.; Ricci, F.; et al. Age-related macular degeneration: Insights into inflammatory genes. J. Ophthalmol. 2014, 2014, 582842. [CrossRef]

79. Hewison, M. Vitamin D and the immune system: New perspectives on an old theme. Endocrinol. Metab. Clin. N. Am. 2010, 39, 365-379, table of contents. [CrossRef] [PubMed]

80. Guillot, X.; Semerano, L.; Saidenberg-Kermanac'h, N.; Falgarone, G.; Boissier, M.C. Vitamin D and inflammation. Joint Bone Spine 2010, 77, 552-557. [CrossRef]

81. Doyle, S.L.; Campbell, M.; Ozaki, E.; Salomon, R.G.; Mori, A.; Kenna, P.F.; Farrar, G.J.; Kiang, A.S.; Humphries, M.M.; Lavelle, E.C.; et al. NLRP3 has a protective role in age-related macular degeneration through the induction of IL-18 by drusen components. Nat. Med. 2012, 18, 791-798. [CrossRef]

82. Yerramothu, P.; Vijay, A.K.; Willcox, M.D.P. Inflammasomes, the eye and anti-inflammasome therapy. Eye (London) 2018, 32, 491-505. [CrossRef]

83. Gee, K.; Guzzo, C.; Che Mat, N.F.; Ma, W.; Kumar, A. The IL-12 family of cytokines in infection, inflammation and autoimmune disorders. Inflamm. Allergy Drug Targets 2009, 8, 40-52. [CrossRef] [PubMed]

84. Schroder, K.; Tschopp, J. The inflammasomes. Cell 2010, 140, 821-832. [CrossRef]

85. Sommer, A.; Fabri, M. Vitamin D regulates cytokine patterns secreted by dendritic cells to promote differentiation of IL-22producing T cells. PLoS ONE 2015, 10, e0130395. [CrossRef] [PubMed]

86. Aranow, C. Vitamin D and the immune system. J. Investig. Med. 2011, 59, 881-886. [CrossRef]

87. Canning, M.O.; Grotenhuis, K.; de Wit, H.; Ruwhof, C.; Drexhage, H.A. 1-alpha,25-Dihydroxyvitamin D3 (1,25(OH)(2)D(3)) hampers the maturation of fully active immature dendritic cells from monocytes. Eur. J. Endocrinol. 2001, 145, 351-357. [CrossRef]

88. Lightman, S.; Calder, V. Is IL-10 a good target to inhibit choroidal neovascularisation in age-related macular disease? PLoS Med. 2006, 3, e364. [CrossRef] [PubMed]

89. Zhao, Q.; Ji, M.; Wang, X. IL-10 inhibits retinal pigment epithelium cell proliferation and migration through regulation of VEGF in rhegmatogenous retinal detachment. Mol. Med. Rep. 2018, 17, 7301-7306. [CrossRef]

90. Theodoropoulou, S.; Copland, D.A.; Liu, J.; Wu, J.; Gardner, P.J.; Ozaki, E.; Doyle, S.L.; Campbell, M.; Dick, A.D. Interleukin-33 regulates tissue remodelling and inhibits angiogenesis in the eye. J. Pathol. 2017, 241, 45-56. [CrossRef]

91. Barbour, M.; Allan, D.; Xu, H.; Pei, C.; Chen, M.; Niedbala, W.; Fukada, S.Y.; Besnard, A.G.; Alves-Filho, J.C.; Tong, X.; et al. IL-33 attenuates the development of experimental autoimmune uveitis. Eur. J. Immunol. 2014, 44, 3320-3329. [CrossRef] 